\title{
Floods as shapers of Dutch cultural identity: media, theories and practices
}

\author{
Lotte Jensen $^{1}$ (D)
}

Received: 16 June 2020 / Accepted: 3 June 2021 / Published online: 11 June 2021

(c) The Author(s) 2021

\begin{abstract}
This article offers a theoretical framework which can be used to study processes of national identity formation through the lens of nature-induced disasters, such as floods. Firstly, it discusses the current state of affairs in historical disaster studies and shows how this field may be enriched by adapting the concept of the 'imagined community' developed in nationalism studies. It furthermore combines insights and concepts from literary studies, cultural studies and memory studies. Secondly, it applies this framework to Dutch history, by discussing the role of flood narratives in shaping a national identity. Studying the Dutch representations of flood disasters illustrates how the nation's identity was shaped by the cultural media that communicated these events. They made use of a recurrent set of tropes, which linked the emergence of national identity to the capacity for coping with floods. This was articulated in a narrative framework, which consisted of standard ingredients, such as the such as the highlighting of horrific events, miraculous rescues, and God's providence. Furthermore, authors foregrounded the involvement of Dutch kings and queens during flood disasters, and framed of the Dutch as being charitable by nature. The analysis of a wide range of media (stories, poems, treatises) shows how processes of national identity formation were shaped in cultural discourses in the aftermath of disasters, a process that is still going on.
\end{abstract}

Keywords Floods $\cdot$ Dutch history $\cdot$ National identity $\cdot$ Disaster studies $\cdot$ Imagined community

\section{Introduction}

In 1825, the Netherlands experienced one of the severest floods in the nation's history. The losses were high: a total number of 380 people were killed and more than 16,700 cattle drowned (Buisman 2019, pp. 797-840). All sorts of media, including newspapers, pamphlets, songs, poems, and memorial books, reported about the disastrous event. Many authors encouraged Dutch citizens to help their fellow-countrymen, with effect. The entire

Lotte Jensen

1.jensen@let.ru.nl

1 Dutch Language and Culture, Radboud University Nijmegen, PO Box 9103, 6500 HD Nijmegen, The Netherlands 
nation, so it seemed, came to the rescue of the victims: an unprecedented amount of more than 2.2 million guilders was raised (Beijer 1826, p. 807). ${ }^{1}$

Paradoxically enough, this short description suggests that a horrific tragedy brought about something good as well: it produced strong communal bonds amongst Dutch people, which led to collective action. The media played an important role in shaping a communal sense of responsibility. Songs, sermons, poems and other writings were used to arouse sympathy for the victims and to enhance empathy with them as well. This sense of belonging together ("we, the Dutch people") was emphasized by representing the disastrous events as a shared experience, which should be overcome by the entire nation. ${ }^{2}$

This article offers a theoretical framework, which can be used to study processes of national identity formation through the lens of nature-induced disasters, such as floods. It combines insights and methods from narratology and media studies, and demonstrates how these can be applied to flood narratives. Scholars in the field of cultural and media studies have shown that media play an essential role in our perception of disasters, because disseminating information and interpreting events take place primarily through narratives and images (Nünning 2013; Juneja and Schenk 2014). Perceptions of disasters are profoundly influenced by a people's cultural habits and beliefs and by the cultural discourses that communicates these events (Schenk 2007; Mauch and Pfister 2009; Juneja and Schenk 2014). In this article, I would like to expand these insights by generating new understanding of how cultural discourses on floods contributed to the shaping of a shared Dutch national identity.

The process of shaping communal bonds in the Netherlands has already been thoroughly studied by cultural historians. ${ }^{3}$ However, combining their insights with an environmental approach would make a noteworthy contribution to disaster studies and other related disciplines as well. Firstly, I will discuss the current state of affairs in historical disaster studies and show how this field may be enriched by adapting the concept of the 'imagined community' developed in nationalism studies. Secondly, I will apply this framework to Dutch history, by discussing the role of flood narratives in shaping a national identity.

\section{State of the art: historical disaster studies}

The field of disaster studies has developed into a flourishing area of research. The interest has risen even more in recent years, as a response to the global awareness that climate change affects natural disasters. Disciplines such as geophysics, economics, risk management, environmental studies and the technical sciences have taken the lead in developing technologies, strategies and policies to prepare for immediate and future catastrophes (Oliver-Smith and Hoffman 1999; Wisner et al. 2012; McEntire 2015; Rodríguez et al. 2018).

Scholars from the humanities have pointed to the necessity of broadening the research in two directions. Firstly, historians have convincingly argued that case studies, derived

\footnotetext{
1 This corresponds to approximately 24 million euro today (value of the guilder/euro: http://www.iisg.nl/ hpw/calculate2-nl.php).

2 The main moral message of commemoration books of the 1825 Zuiderzee Flood in the Netherlands, was to help each other; this was part of an enlightened, religious world view. See Van Dam and Pieters (2018). The motives of donors to nineteenth century floods, including the 1825 Flood, are discussed in Boomsma and Van Dam (2014).

3 To mention some studies: Van Sas (1999), Stein and Pollmann (2010) and Jensen (2017).
} 
from a wide variety of sources, can be used as a 'laboratory' to understand and predict which societies are better at coping with severe crises than others (Curtis 2014; Van Bavel and Curtis 2016; Soens 2018, 2020; Van Bavel et al 2020). Secondly, scholars in the field of historical, cultural and literary studies have demonstrated that a perception of disasters is profoundly influenced by the narratives and images that communicate these events (Schenk 2015; Cecere et al. 2018). Therefore, the role of discursive frameworks, narratives and imagery has to be included in order to fully understand how societies have dealt with disasters in the past.

All these studies underline the difficulty in defining concepts such as 'disaster' and 'catastrophe'. It is difficult and problematic to clearly distinguish between natural and manmade causes for disasters (Schenk 2007, pp. 11-14; Van Bavel et al. 2020, pp. 22-23). Fires, for instance, could be the result of human action, while lack of maintenance could cause levee or dike breaches and floods. In current discussions on climate change, the human factor is indeed omnipresent (McGuire 2014). Moreover, natural and war-related disasters can occur and be discussed within the same context. Nevertheless, disaster studies tend to focus on the impact on societies of nature-induced disasters like earthquakes, volcanic eruptions, animal plagues, droughts, storms, floods, and fires.

As the historians Monica Juneja and Jasper Schenk have argued, transdisciplinary, cultural approaches are called for to fully grasp the impact of disasters upon different societies in different times (Juneja and Schenk 2014). Disasters are reflected upon in a wide variety of media, which influence people's understanding and interpretations of the events. The interpretative models and frameworks used in these discourses are culture-specific and historically embedded (Groh et al. 2003). This requires a historical contextualization, on the one hand, and a thorough analysis of contemporary discourses, on the other. Below, I will propose how such a multidisciplinary framework can be used to investigate the role of historical disasters in the shaping of communal bonds, in particular on the national level, from a cultural-historical perspective.

\section{Multidisciplinary framework}

The suggested theoretical framework represents a crossroad between historical disaster studies and nationalism studies. It combines the use of the well-known concept of 'imagined community' with key concepts from media studies, literary studies and memory studies, including 'representation', 'discursive practice', 'trope', 'narrative template' and 'intertextuality'.

Moments of crisis produce a lasting impact on societal structures. In many cases the population of an area or nation experiences greater feelings of solidarity when faced with severe crises (Koselleck and Richter 2006; Solnit 2010; Meyer et al. 2013; Parker 2013). ${ }^{4}$ These communal bonds can be fruitfully understood from cultural and discursive perspectives by applying the concept of the 'imagined community' from nationalism studies. Nationalism studies have been booming over the last ten years (Smith 2000) and have investigated political, sociological and cultural aspects of the phenomenon. Much attention has been paid to the binding force of imagery spread in the media, in particular with regard

\footnotetext{
${ }^{4}$ Crises such as epidemics may also spark of serious upheaval and social conflicts. See, for example, Curtis (2020) and Censolo and Morelli (2020).
} 
to the nineteenth and twentieth centuries. The underlying assumption is that national identity is shaped in and through mass media (Wodak et al. 2009).

This concept of the imagined community was introduced by the anthropologist and political scholar Benedict Anderson, who perceived modern nations as 'imagined communities' that were shaped by the vernacular 'print-communities' of the nineteenth and twentieth centuries (Anderson 1983). He argued that the convergence of capitalism and print technology made the emergence of these imagined communities possible. Despite not knowing their fellow-members personally, members shared the same images of their community, which were spread through mass media such as newspapers and books, offering them a sense of 'a deep, horizontal comradeship' (Anderson 1983, p. 16). Hence, the national community was essentially a cultural artifact that owed its existence to recurrent images and discourses. Anderson explicitly situated these developments in the nineteenth and twentieth centuries, thus positing the nation as a quintessentially modern phenomenon. Although his concept has inspired many scholars across the globe over the decades, it has also sparked of debate and criticism (Blok et al. 2018).

In recent years, for example, the 'modernist paradigm' has been challenged by a growing number of scholars who situate the origins of nationalism and nationhood in earlier times (Gat 2013; Smith 2013). These so-called traditionalists point to nations that took the form of a national cultural and political community much earlier, such as Sweden, England, Spain, Iceland and the Dutch Republic (Jensen 2016b). Unifying images of these nations were disseminated through a wide range of media, creating a sense of nationhood long before the onset of modernity. Historians have emphasized the importance of early modern print culture, in particular printed religious texts, sermons and catechisms, in the formation of communities based on a common language - indeed explicitly using Anderson's concept of the imagined community (Burke 2013). They show that visual images and printed matter played an essential role in the formation of public opinion and the shaping of local and supra-local communities in pre-modern times as well.

These early modern 'imagined communities' were of a different nature compared to those in the nineteenth and twentieth centuries. For one thing, the volume of printed material was much lower than in modern times. What's more, different geographical communities were addressed. However, the idea that the imagined community is shaped in vernacular print-communities also makes the concept suitable for pre-modernists, if one uses the term in a looser, metaphorical sense, without requiring large circulation figures as a prerequisite (Smith 2000, p. 58). The inclusion of earlier periods makes it possible to trace premodern processes of national community-building and their interconnectedness with the shaping of local identities. In the case of the Netherlands, for example, it has been convincingly argued that the struggle against water and floods constituted an important element in shaping Dutch identity in the early modern period as well (Schama 1987, pp. 34-50).

This national community-building took shape in a wide variety of media. Disaster narratives do not merely reflect what is happening in society, but are powerful agents as well. They produce meaning and content, and thus play an influential role in mapping the minds of people (Chartier and Roche 1989; McQuail 2004). Today, the media generate 'cultures of disaster' by turning them into 'global media events' (Levy 2014, p. 201). ${ }^{5}$ The media are not only providing people with information, they are setting the agenda and serve as powerful tools in the political and ethical debates.

5 The terminology 'cultures of disasters' is derived from Bankoff (2003). 
Representation is a key concept in media studies. Language and images offer representations of the physical and mental worlds in which we play a part. People share similar codes, concepts, images and ideas, with which they interpret the world. Thus, representations are regulated by shared codes and conventions. At the same time, they also produce new meanings and interpretations, which may have an impact on our perceptions of the world. Identity plays a key role as well, as representations express characteristics by which persons or groups are known and recognized. This is a reciprocal relationship: representations are formative elements in constituting collective identities and vice versa (Hall 1997).

With regard to the representation of disasters, the present-day media landscape has changed dramatically in comparison to earlier times, leading to new global, technological and ethical approaches (Van Dijck 2007). Some of the basic insights, however, remain applicable to pre-modern times. Firstly, the way people in different cultures interpret and remember disasters is strongly influenced by the way they are represented and framed in the media. First impressions mediated directly after the event often have a huge impact on later perceptions. Secondly, a 'neutral' or 'objective' account of the happenings is virtually impossible, because a description always relies on narrative structures that inevitably entail some form of interpretation (Nünning 2013).

Literary studies provides us with the tools to unravel the narrative templates used in the discursive field surrounding disasters. The communication on disasters can be seen as a process or a set of discursive practices firmly rooted in a society's culture. It is, for instance, possible to distinguish different discursive frames with regard to disasters, such as a theological response ('providential readings'), authority-driven responses ('institutional responses') and technical responses ('technocratic solutions'), as the historian Adam Sundberg has shown (Sundberg 2015). Each of these frameworks invokes standard argumentative schemes and topical metaphors. Furthermore, subgenres can be distinguished, such as flood narratives, disaster epics, and famine stories. These subgenres often make use of recurrent motifs, tropes, metaphors and commonplaces. Historical accounts, poems and novels often employ a set of standard ingredients and tropes, which, at the same time, express a strong sense of national identity. Literary historians have shown that such tropes are related to an intertext of related textual instances (Corporaal et al. 2012). It is therefore an intertextual issue to establish how representative a given trope may be of more widespread patterns. Tropes have to be contextualized within the fields of other texts and media in order to establish their traditions: to what extent are these tropes echoed, reinforced, and varied upon? Genre conventions should be taken into account as well, as the genre (poetry, novel, short story, newspaper article) also dictates the style and structure of a text.

Finally, memory studies offers valuable insights to help us comprehend the lasting impact of disasters on society. It is through the repetition of images, tropes and narrative schemes that disasters become fixed entities in a region's or nation's history. Scholars of memory have underlined that cultural memory is always mediated and that every memory is 're-presentation, making experiences as it were present again in the form of images, sensations or affects' (Plate and Smelik 2009, p. 4). Collective memories are the result of repeated images and discourses (Frijhoff 1992). Thus, the remembrance of disasters not only happens on the level of individuals, but also on the level of groups. Collective memories play an important role in molding group identities; cultural memory thus provides societies with models of interpretation, concepts and repertoires that are crucial in understanding how people deal with disasters (Schenk 2015, p. 77). On the national level, disasters are often used as points of reference to tell the people's history: the Great Fire of London is firmly rooted in British history, the Famine (1845-1849) is a watershed in the history of Ireland, and the 1953 North Sea Flood is canonical in Dutch history. 
The historian Christian Pfister notes the key role played by memorials in the public sphere across the world in reminding people of the risks they run (Pfister 2011). These 'functional memories', as Pfister calls them, can also be witnessed in the aftermath of the floods of 2007 in South West England. Remembering functioned as a way of coping with the catastrophe, and fostering resilience, a process that can aptly be described with the concept of 'sustainable flood memory' (Garde-Hansen et al. 2017). Memory studies remind us of the fact that although disasters may become fixed points of reference in the nation's history, the memory of these events remains dynamic, changeable and influenced by presentday preoccupations (Erll 2011).

\section{The shaping of a Dutch national identity}

Dutch history provides us with an excellent case to put this theoretical framework into practice. In the case of the Netherlands, the notion of a Dutch identity was expressed particularly strongly in relation to the nation's struggle against the water (Schama 1987, pp. 34-50; pp. 218-220; Esser 2016; Van Dam 2016). Thousands of texts and visual images throughout history refer to the Dutch and their permanent fight against floods. To unravel this vast amount of flood discourses and imagery, a research team has started mapping out patterns, tropes and stereotypical images with respect to this formative element of Dutch culture within a longitudinal perspective. ${ }^{6}$ A comparative approach with other nations is a desideratum for future research; it is to be expected that some aspects of the narrative framework used in flood narratives have a transnational character. ${ }^{7}$ For pragmatic reasons, however, we now solely focus on domestic sources in this text.

In what follows, I will show how communal feelings were cultivated in Dutch cultural flood discourses. I will do this in two steps. I will show that artists and authors made use of a set of recurrent tropes and imagery, which were primarily meant to evoke emotions. Then I will discuss three elements which were framed as being typically Dutch: heroic role models (in particular, the House of Orange), charity, and the vivid memorial culture.

Communal feelings were aroused by using a standard set of tropes and imagery. Every flood-and there were many in Dutch history-led to a stream of paintings and publications, including chronicles, stories, poems, sermons, songs and plays. Although every genre followed its own conventional patterns, the artists and authors often made use of the same narrative patterns and tropes, which consisted of three standard ingredients: describing the horrific happenings by using tropes, telling miraculous stories of rescued people, and emphasizing God's providence. In the first place, authors inserted many horrific scenes of people who, whilst hanging from trees or sitting on top of their houses, were crying for help. Others were floating on rafts or fled to the attic. Much attention was also given to dead cattle and floating dead bodies. All these scenes were based on real experiences, but the literary representation added something extra: the power of the imaginary and emotional language.

\footnotetext{
${ }^{6}$ For more details about this research project, see www.dealingwithdisasters.nl. For some results, see: Van Asperen (2019), Duiveman (2019), Jensen (2019), and Meijer (2020).

7 This becomes evident from comparative studies such as Groh et al. (2003), Schenk (2015), and Bertsch and Trempler (2018).
} 
A typical example is a poem, published in 1825 by G.A.C.W. de Thouars, who worked as a page in the service of King William I. He had not experienced the flood himself, but knew exactly how to touch his readers:

One sees, one stares at, oh God! A dead mother ...

The roof is floating nearer, but who will approach it first.

Desperately one screams: my love! but, softly! ... I hear moaning...

A toddler is lying dead in the arms of the mother! ...

A sweet baby on the ice-cold motherly breast [...].

Two little dead bodies are found, two lovely little dead persons!

[...]

At night the mother puts her precious infant in her rocking cradle.

And shushes it to sleep. And kisses it tenderly.

A severe flood arises and takes the cradle with it.

And soon the little barque is amidst the sea. ${ }^{8}$

In what follows, the poet describes how the cradle turns over and how the baby is swallowed by the sea. He extensively describes the mother's intense grief, whose only consolation is that she will meet her child again in heaven.

This imagery found its origin in the flood panels made after the St Elizabeth Flood of 1421, painted several decades after the catastrophe (Pollmann 2017, pp. 122-129; Van Asperen 2019, Van Asperen et al. 2021). One of the panels showed a baby in a cradle, which reminded the viewers of Moses in the basket, thus reinforcing the religious message behind the scenery. Since then, the floating cradle has become a standard ingredient of flood paintings and literature, even if it led to very unlikely scenes. In a play, written to raise money for the victims of the floods in Zeeland in 1808, a father pulls a basket out of the waves, and then discovers he has just rescued his own son. ${ }^{9}$ Nevertheless, one should realize that the imagery was rooted in reality as well. There are many eye-witness accounts which mention floating cradles carrying infants. In 1825, a sergeant in Kampen, for instance, managed to rescue two small babies, aged fourteen days, from a little basket. They survived the catastrophe (Jensen 2018, p. 21) (Fig. 1).

Furthermore, authors described many miraculous rescues. In this way, they wanted to both warn and console their readers, who, in all circumstances, had to remain faithful. Although God sent disasters to punish people for their sinful behavior, he could also show his benevolence by rescuing them. In an account of the Christmas Flood of 1717, which hit the coastal areas of the Netherlands, Germany and Scandinavia, the preacher Gerardus Outhof meticulously described his experiences. He was born in Amsterdam, but lived and worked during the catastrophe in the German city Emden, which was also affected by the storm. He not only described how he fled to the attic, but he also gave an

\footnotetext{
${ }^{8}$ De Thouars (1825, p. 23): 'Men ziet, men staart, ach God! Een doode moeder aan .../ Het dak drijft nader; doch wie't eerst er heen zal gaan/Wanhopend gilt men uit: mijn ga! maar, zacht! ...'k hoor kermen ... / Een levend wichtje ligt in doode moederarmen! .../ Een lieve zuigeling aan d'ijskoud' moederborst? [...] / Twee lijkjes vind men nog twee lieve kleine dooden! [...] / Des avonds legt zij't wicht in't schomlend wiegje neder, / En sust het dan in slaap. En kust het nog eens teder [...] Een felle vloed daagt op neem het wiegje meê, / En't hulkje drijft weldra op't midden van de zee.

9 The play was written by Adriaan Loosjes, and entitled Ewoud van Lodijke of de ondergang der Zeeuwsche stad Romerswaal (1808). It was about the All Saints Flood of 1555, which swiped away the town of Romerswaal in the province of Sealand.
} 


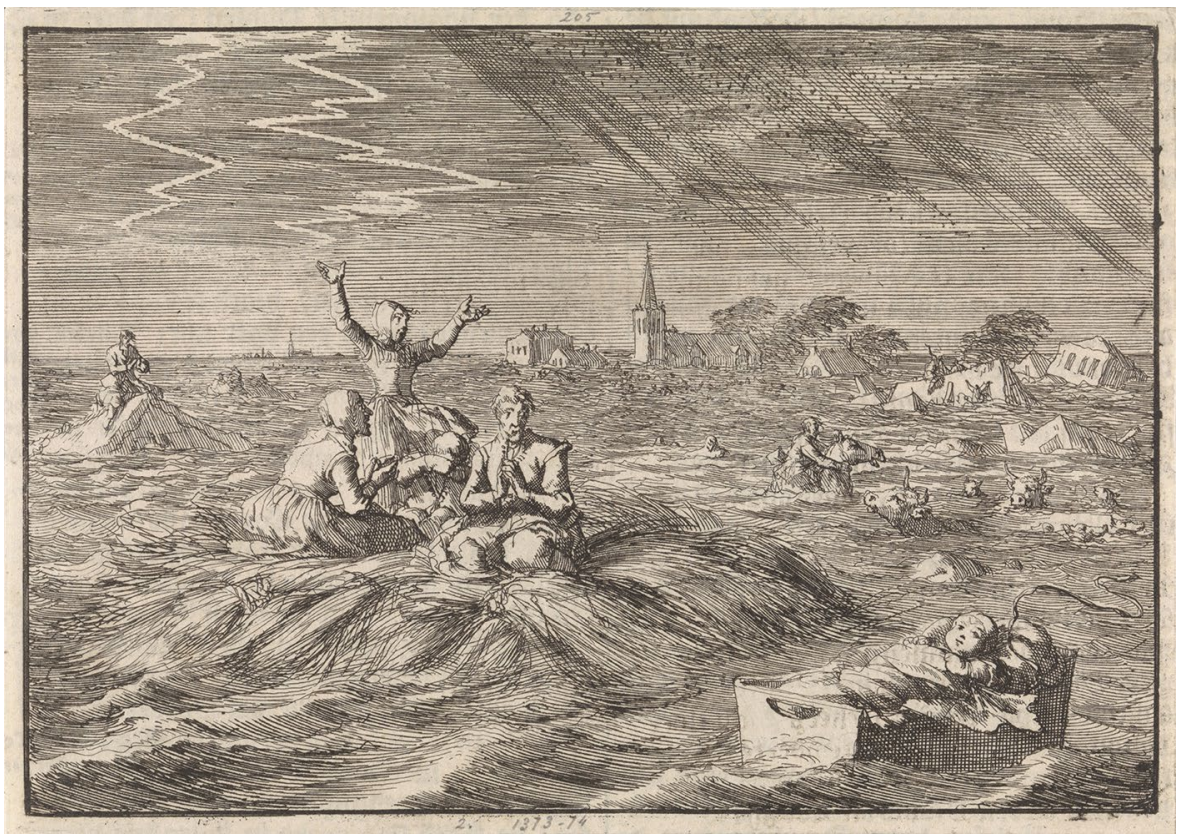

Fig. 1 Illustration by Jan Luyken of the flood in Groningen in 1686 with a baby in a cradle

overview of the events in the nearby provinces. Much attention was given to the miraculous rescues during Christmas Night. The more unlikely the stories, the better. The farmer Roelof Harms, for instance, escaped to the roof of his house, but floated away. He managed to grab a tree near a church in another town, where he spent hours waiting until he could descend into the church. Even more unbelievable was the story of a miller who survived two floods, in 1715 and 1717. Both times he was swept along with the roof of his house along the river Eems, but was saved by hanging for hours from a tree (Outhof 1720, pp. 645-794). Miraculous stories like these were meant to convince atheists or the ungodly, who argued that these events happened accidentally.

All these stories served to convince the readers of God's providence. People were constantly reminded that floods should be seen as a punishment sent by God. The only protection against such punishments was to repent one's sins, as we see in this song about the flood of 1799: 'Devote yourselves to his Will, fall before His power as an obedient servant reverently on your knees and, henceforth, fear His Power' (Jensen 2019, p. 47). Providential readings in the wake of disasters were predominant in early modern society (Walsham 1999; Sundberg 2015; Esser 2016). In the case of the Netherlands, an interesting argument was added: it was argued that it was no coincidence that God decided to send floods as a punishment. Of all the natural elements, water was most present in the Dutch landscape, and therefore God made ample use of this natural source to punish the people: 'In these empty, wet lands, which lay in the water, water is the most prolific element, which God therefore uses to punish the people in these regions to warn people for their sins' (Oudenhoven 1682, p. *3). Stories about horrific events and miraculous rescues followed a standard pattern, and may have strengthened communal religious feelings: repeating the same images and messages again and again added to the sense of belonging together and aroused empathy with the victims. Mourning, repenting 


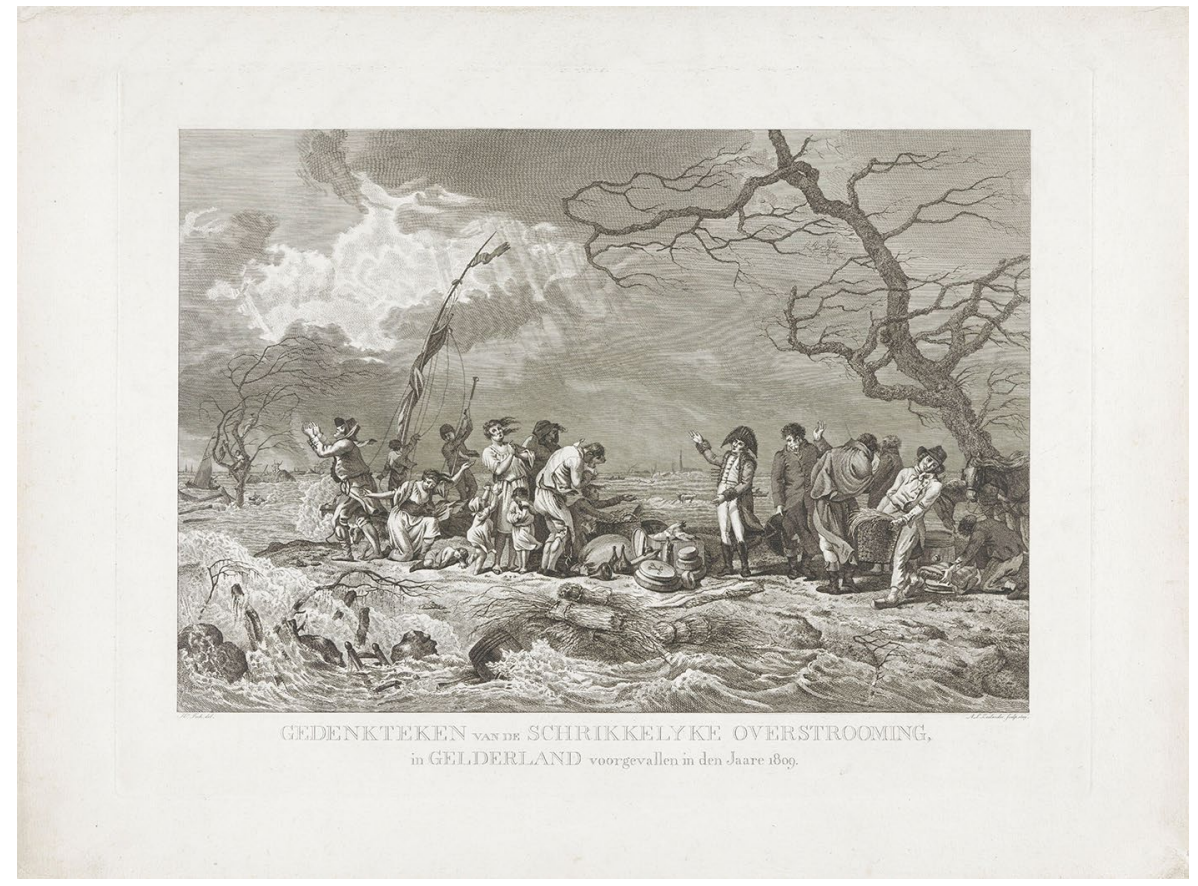

Fig. 2 King Louis Bonaparte visits the devastated areas in Gelderland in 1809, Rijksmuseum Amsterdam

and praying together, were constantly advocated, and generated social (and financial) solidarity (Duiveman 2019).

\section{The use of heroic role models}

The link between Dutch national identity and floods was reinforced by portraying 'typically Dutch' heroes in the wake of disasters. The House of Orange, in particular, played a key role in the struggle against the water. Whenever a flood occurred, members of the royal family rushed to the affected areas to comfort the people and show their empathy. Their caring behavior was praised (and sometimes, although rarely, criticized) in a stream of images and texts, which emphasized their binding role on the national level. Iconic are, for instance, the images of Queen Wilhelmina visiting the victims of the floods of 1916 and 1926, of Queen Juliana, who, in rubber boots, waded through the water to talk to survivors of the 1953 North Sea Flood, and of Queen Beatrix who visited the inhabitants of the flooded province of Limburg in 1995 (Fig. 2).

These monarchs stepped into a tradition, which started with Louis Bonaparte, the first Dutch king, who, on behalf of his brother Napoleon Bonaparte, ruled over the Kingdom of Holland between 1806 and 1810. He was the one who invented the tradition of the monarch being the binding national figure during flood crises. During his reign, the nation was struck by two major floods: in 1808 in Zeeland, and in 1809 in the eastern parts of the country. He seized the opportunity and played a central role in solving these crises. Not only did Louis Napoleon personally donate large sums of money, but he also 


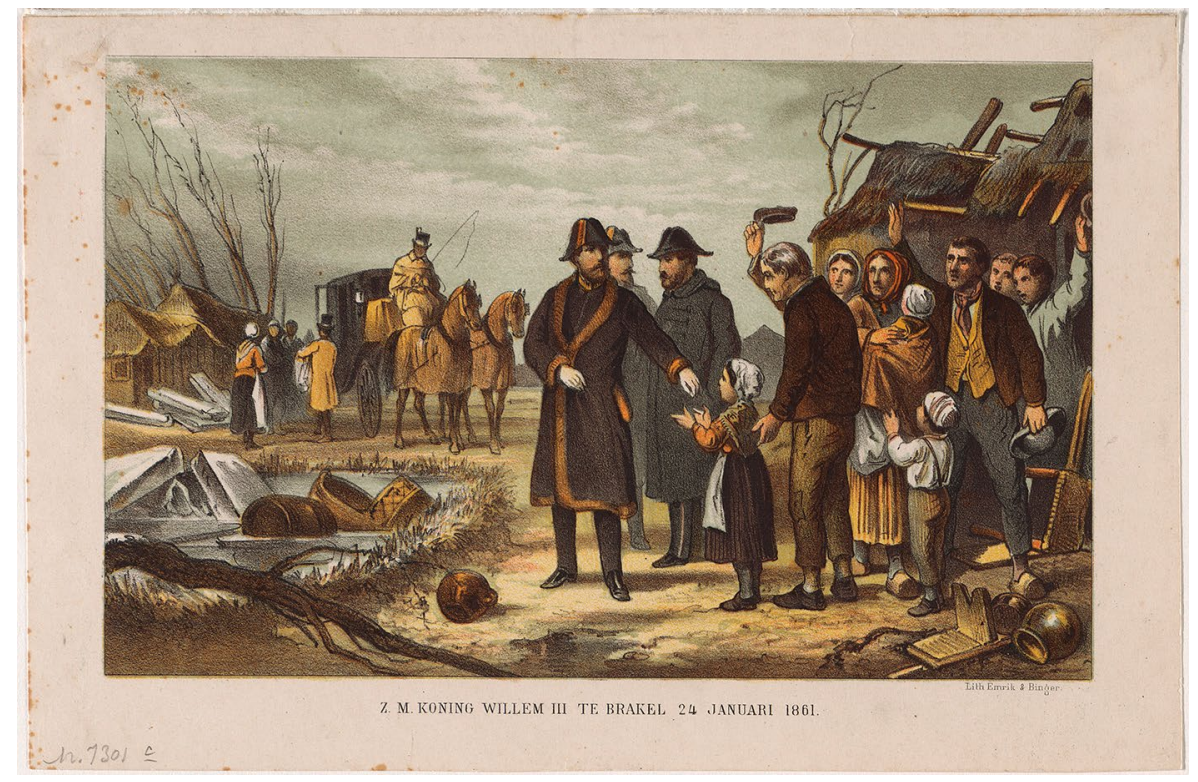

Fig. 3 William III visiting the victims in Gelderland in 1861, Atlas van Stolk

coordinated a national collection. He further more opened up his own palace as a place for refugees and started reorganizing the water institutions and the legal system. Thus, he is considered a major influence on modernizing Dutch water management (Bosch 2007). However, for his reputation and popularity amongst the Dutch people, it was just as important that he personally visited the victims in the affected areas. He even risked his own life, when his carriage was locked in rocky ice masses. All his altruistic activities were covered extensively in the media: prints of his heroic visits, laudatory poems and admiring accounts 'flooded' the nation. This yielded him the nickname 'père des malheureux'. This positive image was shaped not only by state-controlled media, but also affirmed in countless poems and other disaster accounts (Jensen 2016a, b) (Fig. 3).

After Napoleon, every Dutch king or queen presented him- or herself as father or mother of the nation in the wake of disasters. This was particularly the case with King William III, who went to great lengths to help the Dutch people during the floods of 1855 and 1861. He donated large sums of money, coordinated fund-raising activities, and paid several visits to the affected areas. Whatever good he may have done, the media played a crucial role in emphasizing his good deeds and fashioned him into a heroic figure. Many prints depict him as the caring father of the nation amidst his subjects, and in songs and poems he was described as the savior of the Dutch nation (Meijer 2020). In return, 'the Dutch people' thanked him with a monumental State Bible and a monument, erected along one of the dikes. The glorification of the king reached its peak in the aftermath of the flood, which hit large parts of the province of Brabant in December 1880. On 18 February 1881, a special committee organized a 'Flood Festival' in the Palace of Volksvlijt in Amsterdam. Especially for this occasion, a new version of the National Anthem was published, in which King William was praised as the national flood king, a 'Dutch Triton', who personally managed to turn the tide. Again, it was all 


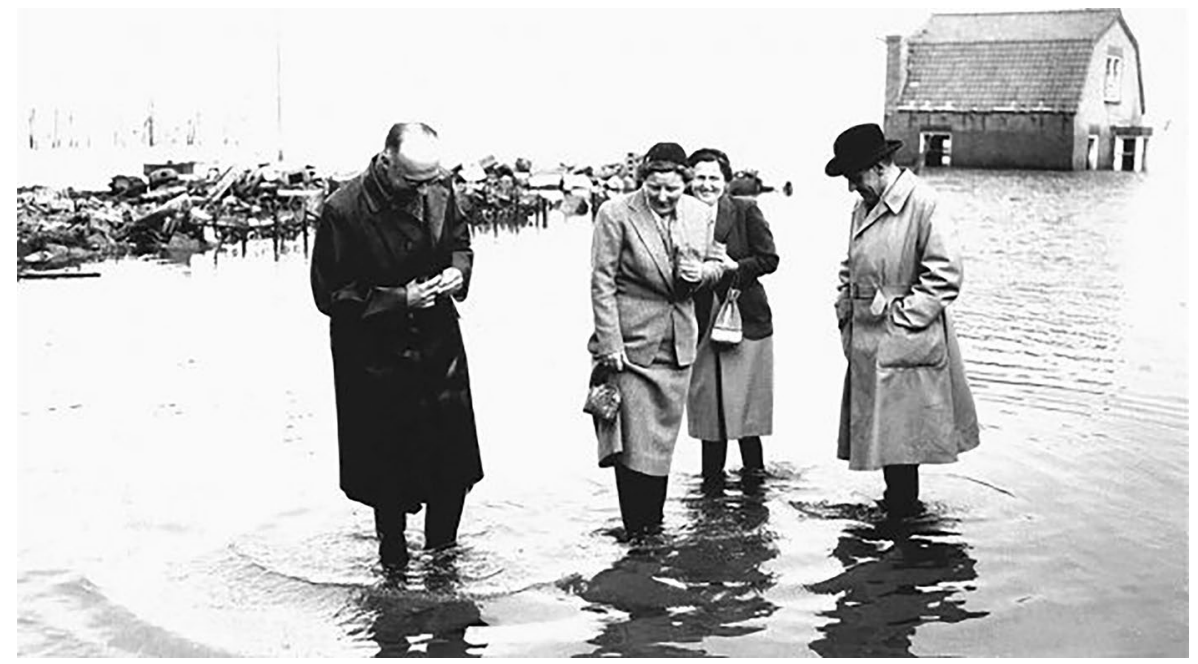

Fig. 4 Queen Juliana wading through the water after the Sea Flood of 1953, ANP

about representation: socialists criticized the media for painting a one-sided image of a king, who, according to them, had lost most of his political credibility (Fig. 4).

Besides the royal family, another category of heroes emerged: citizens who had behaved exceptionally bravely in rescuing other people. Their heroic actions were rewarded with financial bonuses and medals by local and national societies. In 1826, a year after the catastrophe, the Society for the General Benefit (Maatschappij tot Nut van't Algemeen), for example, published long lists of people who had shown exceptionally virtuous behavior by saving other people's lives. Such people were considered to be real 'Dutch heroes' and were celebrated in many occasional poems as well. The poetess Petronella Moens, for instance, wrote: 'who, o Dutch heroic offspring! Who will sketch your noble deeds? Your self-sacrifice in your brothers' latest need?' (Moens 1825, p. 134). The outstanding behavior of the heroes was constantly emphasized. They excelled in simplicity, courage and charity: in short, in being typically Dutch.

\section{Charity as a Dutch characteristic}

Charity was another element which was framed in the cultural media as being typically Dutch. It was a commonplace to encourage readers to be a real Dutch Christian by caring for the victims. The combination of 'showing charity' and 'being Dutch' was mentioned so often in the context of floods, that they became synonyms. Initially, charity was organized incidentally on local scales, but this changed in the course of the eighteenth century, when societies started cooperating with local authorities. During the floods of 1740-1741, aid for victims was, for the first time, organized on a supra-regional level. Groups of prominent citizens from Amsterdam and Rotterdam created a committee to help their fellow-citizens in the eastern parts of the country. The action spread to other cities and was very successful: in the area of Amsterdam alone, an amount of 55,000 guilders was collected (Driessen 2000). The money was used to buy food and goods, which were transported to the affected 
area. The Amsterdam historian Jan Wagenaar, writing about how the money was spent, spoke of 'the old and famous Dutch compassion' (Wagenaar 1776, p. 35).

With every new flood, the cultural media emphasized the charitable nature of the Dutch people, and with success. In the aftermath of the floods of 1784 and 1799, huge amounts were collected: 250,000 and 195,000 guilders (Driessen 2000). In the nineteenth century, the state started playing a more central role. The influence of King Louis Napoleon, who set the example, can hardly be overestimated: the national collection for victims of the flood in 1809 yielded 985,000 guilders (Ewijk 1809, p. 354). This amount was topped by the national collections of 1825,1855 and 1861 .

In the hundreds and hundreds of occasional writings that appeared in the aftermath of these disasters, charity was often framed as typically Dutch, as illustrated by the words of this poet: 'Thank God, that we were also able to find true patriotic hearts with this general catastrophe, who showed their benevolence (and still do as we speak); that the main ingredient of the Dutch character is generosity, which has endured across ages, and which still resides here, and will be present, as long as our people live!' (De Thouars 1825). Charity was also propagated in visual representations of floods. In her analyses of Dutch flood paintings and prints throughout the ages, the art historian Hanneke van Asperen has shown that charity is often singled out as the most important virtue to enhance by Dutch citizens (Van Asperen 2019, 2020).

\section{Culture of remembrance}

Finally, a culture of remembrance contributed to the shaping of a Dutch national identity. In the course of time, an impressive tourist industry emerged, telling the story of the Dutch superiority in taming 'the water wolf'. Again and again, musea, documentaries, educational material and other cultural media have emphasized the superiority of the Dutch in their struggle against the water. I would like to coin this framework, which was central to the Dutch flood narratives, as the 'luctor et emergo' ('I struggle but I emerge') narrative. ${ }^{10}$ The shared memory of the struggle against water, and particularly the capacity to overcome these disasters, are firmly rooted in the national collective memory due to the endless repetition of heroic tales (Jensen 2018, pp. 43-48). From the seventeenth century onwards, authors have praised the water-management capacities of the Dutch: they were capable of conquering new land and preventing new floods. The repetitive imagery provided the Dutch with a national heroic tale, which nourished feelings of national pride. It is still visible today, in the way the Dutch speak about the Delta Works, built after the North Sea Flood of 1953. It is often referred to as one of the modern wonders of the world (Toussaint 2018) and cited as evidence that expertise on water management is part of the Dutch DNA. ${ }^{11}$

That cultural media play an important role in linking Dutch national identity to the struggle against the water can be shown in the example of Hansje Brinker. This 'Dutch' hero was invented by the creative mind of the American author Mary Mapes Dodge in

\footnotetext{
10 The saying originally referred to the struggle of the Dutch against the Spaniards during the Eighty Years War. In the struggle against water, military language, symbols and metaphors were often applied, which makes the proverb very much apt to refer to the struggle against water as well. See on the use of military language in flood discourses: Duiveman 2020.

11 See, for instance: https://www.hollandtradeandinvest.com/key-sectors/water.
} 


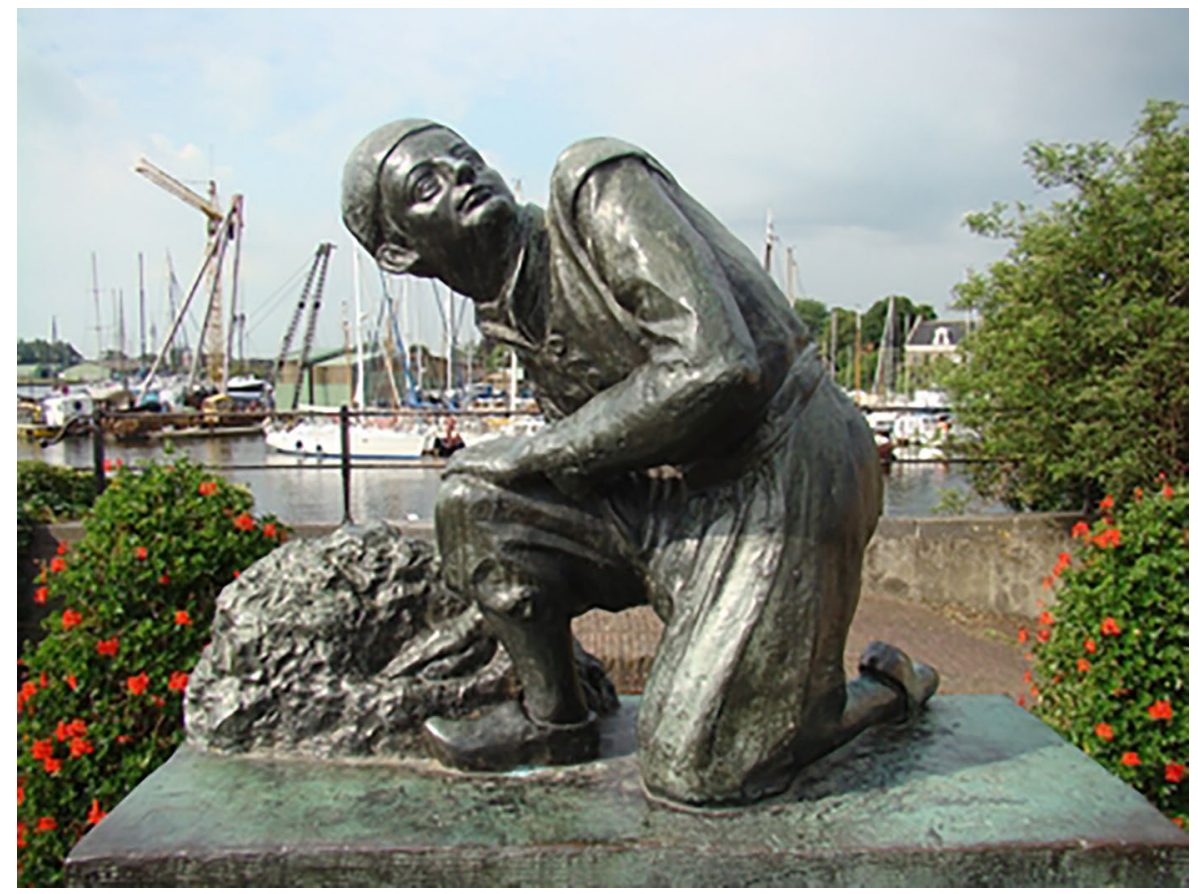

Fig. 5 Statue of Hansje Brinker in Spaarndam, Wikipedia Commons

1865 in her book Hans Brinker or the silver skates. Dodge took her inspiration from a French source. In her book, she describes how a young boy sticks his finger in the dike and successfully prevents the area from flooding. He became the symbol of Dutch heroism in the struggle against the water, but in the countless Dutch translations and adaptions, his American origin gradually vanished (Schultz 2019). The story was entirely appropriated by the Dutch, who celebrated the protagonist with statues, theater plays, souvenirs and even a musical. The title of the children's book simply reads: Hansje Brinker, an original Dutch adventure (Hansje Brinker. Een oer-Hollands avontuur). In the Dutch imagined community, Hansje Brinker became the symbol of Dutch resilience and successful past in struggling against the water. This was a story of the country's greatness that can justifiably be called an 'invention of tradition', as coined by Hobsbawm and Ranger (1983) (Fig. 5).

This is just one out of many examples of how floods and Dutch national identity became intrinsically linked in imagery and tropes spread by a wide variety of media in the course of the centuries. One could, for instance point, at the visual culture on prestigious water works, such as the Delta works (Toussaint 2018). One could furthermore point to the rich song culture that emerged in the seventeenth century. Songs about floods were often reprinted in song books, which allowed for longer circulation periods and enabled songs to become part of collective memory. They were important media to create a sense of community amongst groups of people, on both local and national levels. From the mid-eighteenth century onwards, nearly all songs were national in scope: they situated catastrophes within the larger context of the Netherlands and addressed all the Dutch people (Jensen 2019, pp. 66-67). In the nineteenth century, songs were also used to encourage people to donate money and goods to the victims. In their choice of words, authors went to great 
lengths to arouse empathy in the listeners, who were considered to be part of the same Dutch, patriotic community.

\section{Conclusion}

Studying the Dutch representations of flood disasters illustrates how the nation's identity was shaped by the cultural media that communicated these events. They made use of a recurrent set of tropes, which linked the emergence of national identity to the capacity for coping with severe disasters. This was articulated in a narrative framework, which consisted of standardized ingredients, such as the highlighting of horrific events, miraculous rescues, and God's providence. The connection between flood disasters and Dutchness was further enhanced by foregrounding the involvement of Dutch kings and queens in the direct aftermath of flood disasters. After King Louis Napoleon, every Dutch monarch made efforts to show empathy with victims and help them by donating large sums of money. Monarchs were celebrated in an endless stream of occasional writings and images, suggesting that they played key roles in binding the national community together. The cult of celebrating national heroes was also visible in the social-cultural practice of awarding honorary medals to those who helped the victims.

In cultural flood discourses, the Dutch were also framed as being charitable by nature. This charity culture reached a peak in the nineteenth century, when enormous amounts of money were raised to help victims. In the memorial culture, Christian virtuousness, bravery, and charity were represented as being assets of a typically Dutch mentality that were key in coping with catastrophes. Even a fictional protagonist like Hans Brinker could become a hero in the Dutch imagined community, filled with repenting, brave and charitable citizens. It illustrates how processes of national identity formation were shaped in cultural discourses in the aftermath of disasters.

This all contributed to the claim (or perhaps better phrased as 'myth') that Dutch identity was shaped by successfully 'combatting' the water, a claim that is still being made today. The literary scholar Roland Barthes reminds us in his influential theoretical reflections on myth-making, that myths are constructed by means of language, and often represent a people's past in a flattering, but misleading way (Barthes 1957). Indeed, counternarratives exist as well, in the past as well as the present, ranging from heated religious debates on God's providence, deferred maintenance of the dikes, critical voices on the role of Dutch monarchs in providing relief after floods, and the supposedly charitable nature of the Dutch people. ${ }^{12}$ Nevertheless, precisely the fact that we tend to label these deconstructions of the myth as 'counter-narratives', illustrates the perseverance of the idea that Dutch identity was shaped by the Dutch people's struggle against the water-an image which is firmly rooted in the nation's historical cultural repertoire.

Acknowledgements Research for this article was funded by NWO (The Netherlands Organisation of Scientific Research) and carried out with a Vici grant for the research project Dealing With Disasters: The Shaping of Local and National Identities in the Netherlands, 1421-1890 (Project Number 277-69-002; PI: Lotte Jensen). For more information, see www.dealingwithdisasters.nl. I am grateful to the Project Team Members Hanneke van Asperen, Adriaan Duiveman, Marieke van Egeraat, Fons Meijer, and Lilian Nijhuis. I also thank Marguérite Corporaal and Lindsay Janssen for their comments.

12 In Jensen (2018) many counter-narratives are discussed. 
Open Access This article is licensed under a Creative Commons Attribution 4.0 International License, which permits use, sharing, adaptation, distribution and reproduction in any medium or format, as long as you give appropriate credit to the original author(s) and the source, provide a link to the Creative Commons licence, and indicate if changes were made. The images or other third party material in this article are included in the article's Creative Commons licence, unless indicated otherwise in a credit line to the material. If material is not included in the article's Creative Commons licence and your intended use is not permitted by statutory regulation or exceeds the permitted use, you will need to obtain permission directly from the copyright holder. To view a copy of this licence, visit http://creativecommons.org/licenses/by/4.0/.

\section{References}

Anderson B (1983) Imagined communities: reflections on the origins and spread of nationalism. Verso, London

Bankoff G (2003) Cultures of disaster: society and natural hazards in the Philippines. Routledge, London/ New York

Barthes R (1957) Mythologies. Les Lettres Nouvelles, Paris

Beijer JC (1826) Gedenkboek van Neerlands Watersnood, in Februarij 1825. J. Immerzeel, junior, 's-Gravenhage

Bertsch M, Trempler J (eds) (2018) Entfesselte Natur: Das Bild der Katastrophe seit 1600. Hamburger Kunsthalle, Hamburg

Blok G, Kuitenbrouwer V, Weeda C (eds) (2018) Imagining communities: historical reflections on the process of community formation. Amsterdam University Press, Amsterdam

Boomsma GBR, van Dam PEJM (2014) "Voor de ongelukkigen van de watersnood", Historisch onderzoek naar de donormotieven bij watersnoden in de negentiende eeuw. Tijdschrift Voor Waterstaatsgeschiedenis 24(1):24-37

Bosch T (2007) "t voornaamste onderwerp in Holland": De betekenis van koning Lodewijk voor de nationale waterstaatszorg (1806-1810). Tijdschrift Voor Waterstaatsgeschiedenis 16(2):108-119

Buisman J (2019) Duizend jaar weer, wind en water in de Lage Landen, vol 7. Uitgeverij Van Wijnen, Franeker, pp 1800-1825

Burke P (2013) Nationalisms and vernaculars. In: Breuilly J (ed) The Oxford handbook of the history of nationalism. Oxford University Press, Oxford, pp 1500-1800

Cecere D, De Caprio C, Gianfrancesco L, Palmieri P (eds) (2018) Disaster narratives in early modern naples: politics, communication and culture (trans: Enrica Maria Ferrara). Viella, Rome

Censolo R, Morelli M (2020) Covid 19 and the potential consequences for social stability. Peace Econ Peace Sci Public Policy. https://doi.org/10.1515/peps-2020-0045

Chartier R, Roche D (1989) Livres et presse: véhicules des idées. In: Transactions of the seventeenth international congress on the enlightenment. Oxford University Press, Oxford, pp 585-603

Corporaal M, Cusack C, Janssen L (2012) Introduction. In: Corporaal M, Cusack C, Janssen, L (eds) Recollecting hunger, an anthology: cultural memories of the great famine in Irish Fiction, 1847-1921. Irish Academic Press, Dublin, pp 1-22

Curtis, D R (2014) Coping with Crisis. The Resilience and Vulnerability of Pre-Industrial Settlements. Farnham: Ashgate 2014

Curtis DR (2020) Preserving the ordinary: social resistance during the second pandemic plagues in the low countries. In: Gerrard C, Forlin P, Brown PJ (eds) Waiting for the end of the world? New perspectives on natural disasters in Medieval Europe. Routledge, London, pp 280-297

Dam PJEM, Pieters H (2018) Enlightened ideas in commemoration books of the 1825 Zuiderzee flood in the Netherlands. In: Brand P, Go S, Verstegen W (eds) Navigating history: economy, society, knowledge, and nature: essays in honour of Prof. Dr. C.A. Davids. Brill, Leiden, pp 275-297

de Thouars GACW (1825) Tafereel van den ramp in Nederland, geleden door den watersnood in 1825. Dichtstuk. J.J. Thompson, Rotterdam

Driessen A (2000) Hulpverlening na overstromingsrampen in het Nederlands rivierengebied. Groniek 147:185-198

Duiveman A (2019) Praying for (the) community: disasters, ritual and solidarity in the eighteenth-century Dutch Republic. Cult Soc Hist. https://doi.org/10.1080/14780038.2019.1674619

Duiveman A (2020) Demilitariseer de polder: Oorlogsmetaforiek, geschiedschrijving en de toekomst van de Nederlandse delta. In: Jensen L, Duiveman A (eds) Welke verhalen vertellen we? Narratieve strategieën rondom waterbeheer en zeespiegelstijging. Radboud Universiteit, Nijmegen, pp 36-47

Erll A (2011) Memory in culture. Palgrave McMillan, New York 
Esser R (2016) Narratives of resilience on the Dutch coast in the seventeenth century. Low Ctries Stud 40(2):97-107

Ewijk H (1809) Geschiedkundig verslag der dijkbreuken en overstroomingen, langs de rivieren in het Koninkrijk Holland. Voorgevallen in den louwmaand MDCCCIX, vol 2. Joh. Allart en Jac. Ruys, Amsterdam

Frijhoff W (1992) Identiteit en identiteitsbesef: De historicus en de spanning tussen verbeelding, benoeming en herkenning. Bijdragen En Mededelingen Betreffende De Geschiedenis Der Nederlanden 107(4):614-634

Garde-Hansen J, McEwen L, Holmes A, Jones O (2017) Sustainable flood memory: remembering as resilience. Mem Stud 10(4):384-405

Gat A (2013) Nations: the long history and deep roots of political ethnicity and nationalism. Cambridge University Press, Cambridge

Groh D, Kempe M, Mauelshagen F (eds) (2003) Naturkatastrophen, Beiträge zu ihrer Deutung, Wahrnehmung und Darstellung in Tekst und Bild von der Antike bis ins 20s Jahrhundert. Gunter Narr Verlag, Tübingen

Hall S (1997) Representation: cultural representations and signifying practices. Sage Publications, London

Hobsbawm E, Ranger T (1983) The invention of tradition. Cambridge University Press, Cambridge

Jensen L (2016) "See our succumbing Fatherland, overwhelmed by disaster, woe and strife": coping with crisis during the reign of Louis Bonaparte. Dutch Crossing 40(2):151-164

Jensen L (ed) (2016b) The roots of nationalism: national identity formation in early Modern Europe, 16001815. Amsterdam University Press, Amsterdam

Jensen L (2017) Celebrating peace: the emergence of Dutch identity, 1648-1815. Nijmegen, Vantilt

Jensen L (2018) Wij tegen het water: Een eeuwenoude strijd. Vantilt, Nijmegen

Jensen L (2019) Disaster upon disaster inflicted on the Dutch: singing about natural disasters in the Netherlands, 1600-1900. BMGN 134(2):45-70. https://doi.org/10.18352/bmgn-lchr.10449

Juneja M, Schenk GJ (eds) (2014) Disaster as image: iconographies and media strategies across Europe and Asia. Verlag Schnell \& Steiner, Regensburg

Kosseleck R, Richter M (2006) Crisis. J Hist Ideas 67(2):1-31

Levy D (2014) The mediat(izat)ion) of disasters and the cosmopolitization of time. In: Juneja M, Schenk GJ (eds) Disaster as image: iconographies and media strategies across Europe and Asia. Verlag Schnell \& Steiner, Regensburg, pp 195-203

Mauch C, Pfister C (eds) (2009) Natural disasters, cultural responses: case studies toward a global environmental history. Lexington Books, Lanham

McEntire DA (2015) Disaster response and recovery: strategies and tactics for resilience, 2n edn. Wiley, Hoboken

McGuire B (2014) Catastrophes: a very short introduction. Oxford University Press, Oxford

McQuail D (2004) Introduction: overview of the handbook. In: Downing JHD (ed) The Sage handbook of media studies. Sage Publishing, Thousand Oaks, pp 1-16

Meijer F (2020) Vorst in het vizier: Nationalisme en verbeelding van de Oranjes na grote rampen in de negentiende eeuw. In: Jensen L (ed), Crisis en catastrofe: De Nederlandse omgang met rampen in de lange negentiende eeuw. Theme issue De Moderne Tijd 3/4, pp 294-320

Meyer C, Patzel-Mattern K, Schenk GJ (eds) (2013) Krisengeschichte (n). "Krise" als Leitbegriff und Erzählmuster in Kultwissenschaftlichter Perpektive. Franz Steiner Verlag, Stuttgart

Moens, P (1825) Na de rampvolle overstroomingen in mijn vaderland, gedurende den nacht tusschen den 3den en 4den februarij 1825. In: Letterkundig magazijn, van wetenschap, kunst en smaak (2). G. van Dijk, Amsterdam, pp 132-137

Nünning A (2013) Krise als Erzählung und Metaphor: Literaturwissenschaftlichte Bausteine für eine Metapholorlogie und Narratologie von Krisen. In: Meyer C, Patzel-Mattern K, Schenk GJ (eds) Krisengeschichte(n), Krisengeschichte (n). "Krise" als Leitbegriff und Erzählmuster in Kultwissenschaftlichter Perpektive. Franz Steiner Verlag, Stuttgart, pp 117-44

Oliver-Smith A, Hoffman SM (eds) (1999) The angry earth: disaster in anthropological perspective. Routledge, New York/London

Outhof G (1720) Verhaal van alle hoge watervloeden, in meest alle plaatsen van Europa [...], 2nd edn. A. van Laar, Embden

Parker G (2013) Global crisis, war, climate change and catastrophe in the seventeenth century. Yale University Press, New Haven

Pfister C (2011) "The Monster Swallows You": disaster memory and risk culture in Western Europe, 15002000. RCC Perspect. https://doi.org/10.5282/rcc/5583

Plate L, Smelik A (eds) (2009) Technologies of memory in the arts. Palgrave Macmillan, Basingstoke

Pollmann J (2017) Memory in early Modern Europe, 1500-1800. Oxford University Press, Oxford 
Rodríguez H, Donner W, Trainor JE (eds) (2018) Handbook of disaster research. Springer, Heidelberg

Schama S (1987) The embarrassment of riches: an interpretation of Dutch culture in the golden age. Fontana Press, London

Schenk GJ (2007) Historical disaster research: state of research, concepts, methods and case studies. Hist Soc Res 32(3):9-31

Schenk GJ (2015) "Learning from history": chances, problems and limits of learning from natural disasters. In: Krüger F, Bankoff G, Cannnon T, Orloswiki B, Schipper ELF (eds) Cultures and disasters: understanding cultural framings in disaster risk reduction. Routledge, New York, pp 72-86

Schultz B (2019) The story of the Dutch boy who prevented a flooding disaster: origin and variations of the theme. Water Hist 11(3/4):207-231

Smith A (2000) The nation in history: historiographical debates about ethnicity and nationalism. University Press of New England, Lebanon

Smith A (2013) Nationalism: theory, ideology, history, Sec. Cambridge University Press, Cambridge

Soens T (2018) Resilient societies, vulnerable people: coping with north sea floods before 1800 . Past Present 241:143-177

Soens T (2020) Resilience in historical disaster studies: pitfalls and opportunities. In: Endress M, Clemens L, Rampp B (eds) Strategies, dispositions and resources of social resilience: a dialogue between medieval studies and sociology. Springer VS, Wiesbaden, pp 253-274

Solnit R (2010) A paradise built in hell: the extraordinary communities that arise in disaster. Penguin books, New York

Stein R, Pollmann J (eds) (2010) Networks, regions and nations: shaping identities in the low countries, 1300-1650. Brill, Leiden/Boston

Sundberg A (2015) Floods, worms and cattle plague: nature-induced disaster at the closing of the Dutch golden age, 1672-1764. Ph.D. dissertation, Kansas University

Toussaint B (ed) (2018) Modern wereldwonder: Geschiedenis van de Deltawerken. Boom, Amsterdam

van Asperen H (2019) Charity after the flood: the Rijksmuseum's St Elizabeth and St Elizabeth's Flood Altar Wings. Rijksmus Bull 67(1):36-59

van Asperen H (2020) Disaster and discord: Romeyn de Hooghe and the Dutch State of ruination in 1675. Dutch Crossing. https://doi.org/10.1080/03096564.2020.1809285

van Asperen H, Eekhout M, Jensen L (eds) (2021) De grote en vreeselike vloed: De Sint-Elisabethsvloed 1421-2021. Amsterdam University Press, Amsterdam

van Dam PJEM (2016) An amphibious culture: coping with floods in the Netherlands. In: Coates P, Moon D, Warde P (eds) Local places, global processes. Oxford University Press, Oxford, pp 78-93

van Dijck J (2007) Mediated memories in the digital age. Stanford University Press, Stanford

van Oudenhoven J (1682) Antiquitates Cimbricae Renovatae, Dat is, vernieude oudtheden der Cimbren. Of een raer Verhael van de Cimbren en de Cimbersche Vloet. Ende Van 't hoogh Water 1681. en hoogen Vloet van den 26. January. 1682. Symon Swart, Haerlem

van Sas NCF (ed) (1999) Vaderland: Een geschiedenis vanaf de vijftiende eeuw tot 1940. Amsterdam University Press, Amsterdam

van Bavel B, Curtis D (2016) Better understanding disasters by better using history: systematically using the historical record as one way to advance research into disasters. Int J Mass Emerg Disasters 34(1):1-32

van Bavel B, Curtis DR, Dijkman J, Hannaford M, de Keyzer M, van Onacker E, Soens T (2020) Disasters and history: the vulnerability and resilience of past societies. Cambridge University Press, Cambridge

Wagenaar J (1776) Verzameling van historische en politieke tractaaten. Yntema en Tieboel, Amsterdam

Walsham A (1999) Providence in early Modern England. Oxford University Press, Oxford

Wisner B, Gaillard JC, Kelman I (eds) (2012) Handbook of hazards and disaster risk reduction and management. Routledge, London/New York, pp 131-141

Wodak R, De Cillia R, Reisigl M, Liebhart K (2009) The discursive construction of national identity, 2nd edn. Edinburgh University Press, Edinburgh

Publisher's Note Springer Nature remains neutral with regard to jurisdictional claims in published maps and institutional affiliations. 